\title{
Primacy of Awareness Raising on Uptake of Access To Government Procurement Opportunities by The Youth A Study of Isiolo County
}

Ann Teresa Wanjiru Kangethe, Fredrick Ephraim Khaunya Mukabi, David Newton Simiyu

To Link this Article: http://dx.doi.org/10.6007/IJARBSS/v11-i4/9665

DOI:10.6007/IJARBSS/v11-i4/9665

Received: 06 February 2021, Revised: 10 March 2021, Accepted: 28 March 2021

Published Online: 16 April 2021

In-Text Citation: (Kangethe et al., 2021)

To Cite this Article: Kangethe, A. T. W., Mukabi, F. E. K., \& Simiyu, D. N. (2021). Primacy of Awareness Raising on Uptake of Access To Government Procurement Opportunities by The Youth A Study of Isiolo County. International Journal of Academic Research in Business and Social Sciences, 11(4), 230-247.

Copyright: @ 2021 The Author(s)

Published by Human Resource Management Academic Research Society (www.hrmars.com)

This article is published under the Creative Commons Attribution (CC BY 4.0) license. Anyone may reproduce, distribute, translate and create derivative works of this article (for both commercial and non-commercial purposes), subject to full attribution to the original publication and authors. The full terms of this license may be seen at: http://creativecommons.org/licences/by/4.0/legalcode

Vol. 11, No. 4, 2021, Pg. 230 - 247

Full Terms \& Conditions of access and use can be found at http://hrmars.com/index.php/pages/detail/publication-ethics 


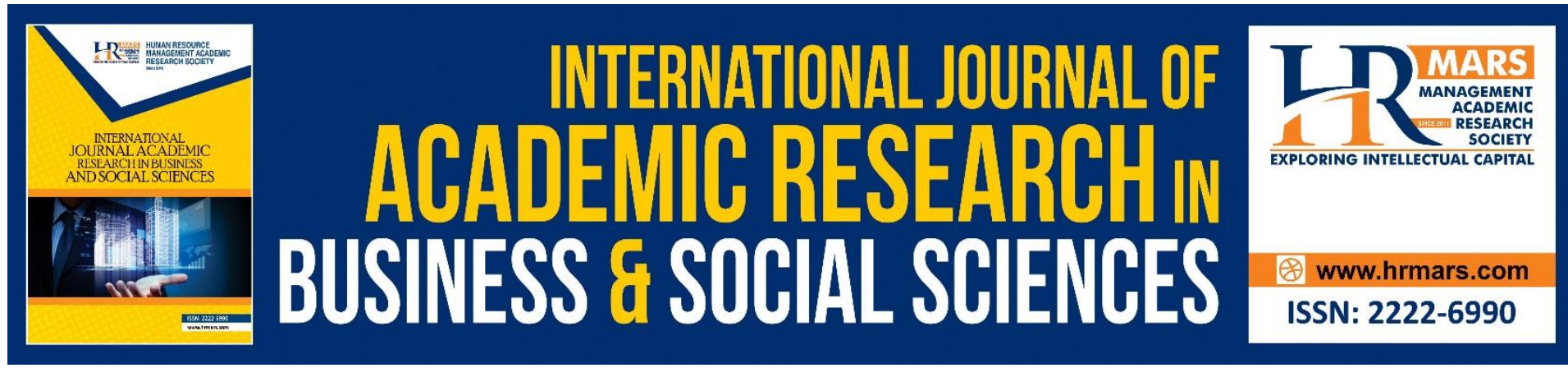

\title{
Primacy of Awareness Raising on Uptake of Access To Government Procurement Opportunities by The Youth A Study of Isiolo County
}

\author{
Dr. Ann Teresa Wanjiru Kangethe, Dr. Fredrick Ephraim \\ Khaunya Mukabi, David Newton Simiyu \\ Kenya School of Government, Embu Campus \\ Email: ann.kangethe@ksg.ac.ke, fredrick.mukabi@ksg.ac.ke, david.simiyu@ksg.ac.ke
}

\begin{abstract}
One of the most fundamental initiatives by the Kenyan Government is to empower the Youth, Women and Persons With Disabilities (PWDs) to access, participate and benefit from at least thirty percent (30\%) of Government Procurement Opportunities through preferential treatment while they try to seek Government Procurement Prospects. The major purpose of the initiative is to accelerate the growth of enterprises owned by Youth, Women and PWDs. However, taking cognizant of the myriad challenges encountered, the determinants of these strategic interventions and how they influence the uptake of this opportunity is not clear and hence this study while narrowing on the independent parameter of Awareness Raising pursued to correlate with the outcome variable which was the Uptake of Access to Government Procurement Opportunities (AGPO).

The study employed the descriptive research design with inferential statistics as tools of analysis, and with a sample of 55 respondents drawn from the Three (3) Sub-Counties, namely; Isiolo, Garbatulla, and Merti, all in Isiolo County in Kenya. The researchers interconnected the independent variable with the dependent variable. The study found that Awareness Raising had statistically significant strong positive correlation with the Uptake of AGPO.The study concluded that Awareness Raising significantly influenced the Uptake of AGPO, as it emerged that access to information on AGPO was not an impediment and that there were sensitizations workshops on AGPO which had enabled them to seize opportunities in AGPO. From the findings, the study recommended that, there is need for Awareness Raising on AGPO by the County Government of Isiolo and other key players such as Development Partners, Management Development Agencies(MDAs), Faith Based organizations (FBOs) and Non-Governmental Organizations (NGOs).
\end{abstract}

Keywords: Primacy, Access to Government Procurement Opportunities, AGPO, Awareness Raising, Uptake 


\section{Statement of the Research Problem}

The AGPO initiative by the Government of Kenya (GOK) through the National Treasury was to enhance the growth of enterprises owned by Youth, Women and PWDs to access, participate and benefit from the various Government Procurement Opportunities.

This was to be made conceivable through the implementation of the legal requirements envisioned in the Constitution of Kenya (COK) 2010, article 227 and executed through the Public Procurement and Disposal Act (PPADA), 2015 through which thirty percent (30\%) of Government Procurement Opportunities were to be set aside specifically for enterprises owned by these groups.

However, the said beneficiaries have not effectively seized this opportunity as reflected by the Annual Reports from the National Treasury and research by NGOs.

The National Treasury Report on AGPO, 2018 indicated that, less than 40\% of the Youth mainly in rural areas had embraced the challenge to utilize this opportunity and procurement bodies were finding it difficult to engage these beneficiaries due to various reasons. Correspondingly, research by Hivos East Africa in 2018 on 'Kenya's Efforts to Empower Youth, Women and PWDs. through Public Procurement' indicated that only thirty-six (36\%) of applicants reported to have won tenders, sixty-six (66\%) lack capital and sixty percent $(60 \%)$ had challenges in getting paid after delivery. Further, the research by Hivos (2018) showed that procurement procedures and criteria are complex, burdensome and costly for new entities.

Awareness Raising was studied as a causal variable in this research work. It is a concept that addresses the knowledge of individuals, the public as well as different organizations. It has been noted that, when awareness creation is embraced by Youth through various intervention approaches, it has the potential to accelerate productivity growth in the economy. However, under normal circumstances, it has been established that the Youth are usually left idle hence triggering social, political and economic instability and underdevelopment. There are diverse Awareness Raising strategies that have been used worldwide such as: workshops, campaigns, seminars, conferences, leveraging on advanced technology and identification of youth talents through drama and creative arts. All these aim at re- kindling enthusiasm, action, and most importantly change of attitudes and mind-sets of the Youth. Efficacious integration of the Youth in the economy through the government procurement opportunities expedites the suppression of poverty and creates a circle of growth and investment(Njeri \& Getuno, 2016).

The purpose of this study therefore, was to establish the Primacy of Awareness Raising on Uptake to AGPO by the Youth, Women and PWDs who constitute the low-income cadre as per the Kenya National Housing and Population Census of 2019.

\section{Research Objective}

To determine the Primacy of Awareness Raising on Uptake of AGPO by the Youth in Isiolo County.

\section{Research Hypothesis}

The hypothesis discussed, assumed that there was a relationship between the research variable; Awareness Raising and Uptake of AGPO after review of literature.

$\mathbf{H}_{\mathbf{o 1}}$ : Awareness Raising does not have a statistically significant relationship with the Uptake of AGPO by the Youth in Isiolo County. 


\section{Conceptual Framework}

The study conceptualized that Awareness Raising spurs the Uptake of AGPO. The relationship is shown in Figure 1.

\section{Independent Variable}

\section{Dependent Variable}

\section{Awareness Raising}

Key Indicators:

- Knowledge on AGPO

- AGPO Registration

- Regular Access to Education Information and Communication Materials on AGPO

- AGPO sensitization workshops

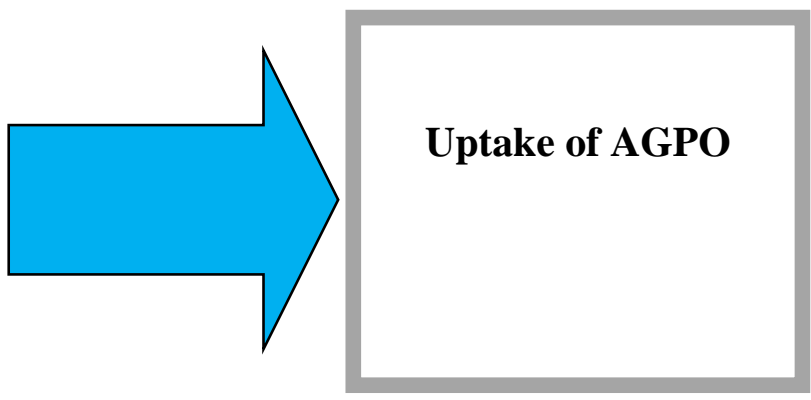

- Level of Utilization of AGPO Knowledge and opportunity

Figure 1: Conceptual Model

(Source: Authors. 2019)

\section{Literature Review}

\section{Theoretical Framework}

The research applied two (2) theories to explain the variables of the study, that is: The Seven Doors Social Marketing Approach by Les Robinson (1998) and Behavior Change Model developed by Burnet Institute in Australia and espoused by Oxfam International Youth Parliament in 2005.

\section{a. The Seven Doors Social Marketing Approach}

The theory was used to explain the relationship between Awareness Raising and Uptake to AGPO by the Youth in Isiolo County. The theory aimed at cautioning against the assumption that successful provision of information on AGPO through Awareness Raising would automatically result in creating a lasting behavior change.

Robinson posed a rhetorical question "What if people already know plenty about the problem and have a pretty good idea of what they should do and want to do it, but something else is stopping them?" He addressed this question by identifying seven (7) steps to social change:

i. Knowledge - knowing there is a problem

ii. Desire - imagining a different future

iii. Skills - knowing what to do to achieve that future

iv. Optimism - confidence or belief in success

v. Facilitation - resources and support infrastructure

vi. Stimulation - a compelling stimulus that promotes action and, 
vii. Reinforcement - regular communications that reinforce the original message or messages

This information is illustrated in Figure 2 on the Seven Doors Social Marketing Model.
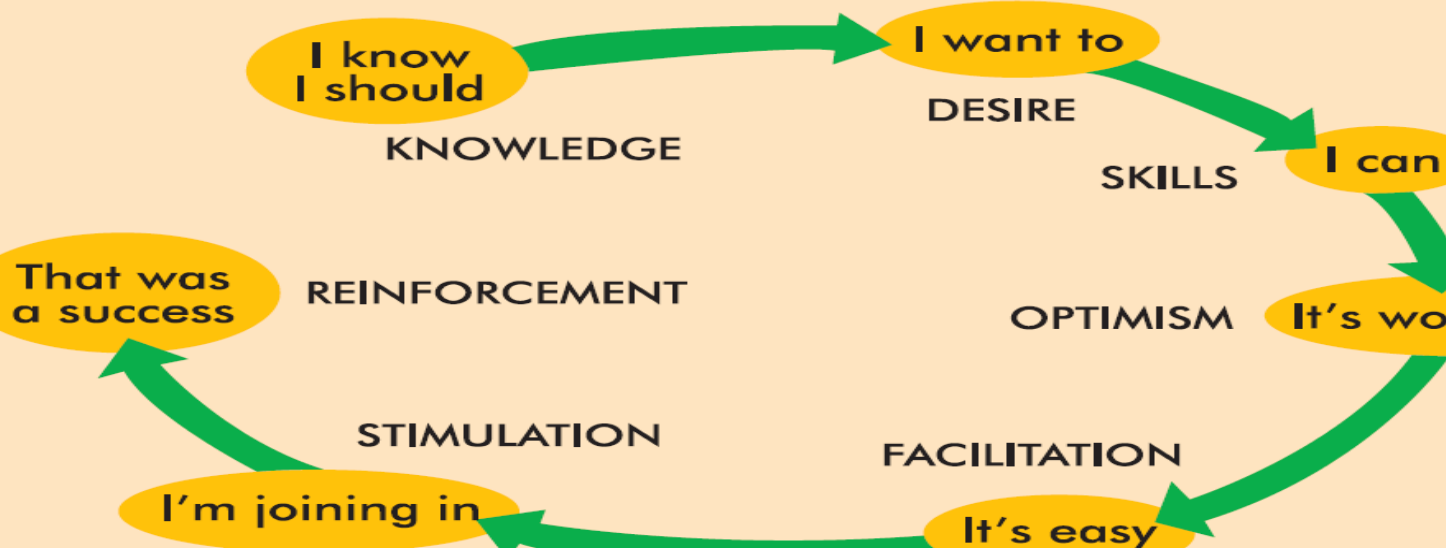

Figure 2: The Seven Doors Social Marketing Model Source: (Sayers Richard, 2006)

Robinson observed that each step has its own unique obstacles that have to be overcome through appropriate communication and education strategies. He envisaged each step or obstacle as a door that must be opened in the context of Awareness Raising in order to accomplish long-lasting social change of a Youth that is optimistic, entrepreneurial with profitable and growth-oriented ventures that contribute to national development agenda.

\section{b. Behavior Change Model}

The advocates of Behavior Change Model as shown in Figure 3, identified five (5) distinct phases of Behavioral change: Pre-contemplation, Contemplation, Preparation, Action and Maintenance.

The Oxfam authors summarized the five (5) stages as:

i. Knowledge, implying pre-contemplation which demonstrates awareness of the desired behavior.

ii. Approval, that is, contemplation or voicing endorsement and support for the behavior.

iii. Intention, inferring to preparation or making the decision to adopt the behavior, whether conditionally or unconditionally.

iv. Practice, denoting action and demonstrating commitment to the behavior in a consistent and sustainable way.

v. Advocacy, suggesting maintenance and the need to inspire others to adopt the behavior, intention and practice. 


\section{Figure 3: Behavior Change Model}

Source: (Sayers Richard, 2006)

The Behavior Change Model, specifies the step by step stages that the Youth need to undertake to meaningfully and effectively participate in AGPO to realize the long lasting social and economic transformation in Kenya.

\section{Empirical Review of Literature}

A huge body of literature exists that examine various bases of the utilization of AGPO interventions by the target group. In Kenya, AGPO is an affirmative action intended to empower Youth, Women and PWDs, by setting aside thirty percent $(30 \%)$ of all public procurement for the targeted group (PPADA, 2015). The AGPO initiative is founded in the COK, 2010, article 227 on the fair, equitable, transparent and cost-effective public procurement of goods and services, article 55 on affirmative action and the PPADA, 2015.

The scholarly works by Nkonge et al. 2013 undertaken in Thika on challenges facing Small and Medium Enterprises (SMEs) Suppliers when bidding for Government tenders, established that the existence of the legal framework makes it difficult for upcoming SMEs to favorably compete with the established firms in the market.This acted as a deterrence for SMEs to participate in the public procurement.

The International Trade Centre (ITC) conducted a study in 2014 on challenges that face women and youth in Developed and Developing economies in Government procurement.

The study established that lack of information about tender opportunities, overly complex and burdensome tender procedures, and failure by those agencies to promptly pay womenbased businesses influenced Uptake of AGPO by the intended groups.

According to UN Women Report of 2006, women entrepreneurs face many handles when participating in public procurement which include; Government rules and regulations, lack of access to finance, assets, information technology, infrastructure and other facilities that enable their efficiency and business growth.

Nduta et al. (2015) undertook a study with the main objective to determine the dynamics heartrending Youth participation in Public Procurement in Mombasa County. The study documented that, issues related to awareness on compliance, registration, effective regulations and financial availability influenced participation of the Youth in the Public Procurement.

A study by Ngugi and Mugo (2007) on the operation and effectiveness of procurement activities in Ministries in Kenya, acknowledged that there was need for procurement functions to be carried out by competent staff with high professional and ethical standards, using sound procedures anchored on appropriate policies and regulations.

A study to determine Compliance of AGPO regulations for Youth, Women and PWDs, in Public Universities in Kenya was carried out by Mwangi in 2017. The research findings publicized that prequalification criteria adversely subsidized to the level of compliance with AGPO. The study further revealed that splendid selection procedures lead to a higher level of compliance with AGPO for exceptional groups in Kenya.

As revered in the Kenyan laws, the Government of Kenya sets aside thirty percent $(30 \%)$ of its expenditure for the Youth, Women and PWDs in every Financial Year.

A report of a training held in 2016 by Kenya Private Sector Alliance (KEPSA) on AGPO expressed the need for Youth to take advantage of the initiative since the amount set aside was quite substantial. 
As noted, a number of challenges have made the Uptake of AGPO opportunities by the Youth not optimal. These challenges include but not limited to: inadequate awareness of the available opportunities and knowledge of Government procurement processes as well as insufficient funds to finance tenders.

The mandatory requirements of AGPO necessitates that the Youth need to take grasp of:

a. Registration of a business name; this can be a sole proprietor, partnership or company.

b. Acquisition of Personal Identification Number (PIN) ; a sole proprietor's personal PIN can be used for the business but for partnerships and companies their identity is different from ownership for Kenya Revenue Authority(KRA) tax purposes.

c. Acquisition of KRA tax compliance certificate; this is easily accessible online.

d. Acquisition of AGPO certificate; this facilitates the identification of an individual as a Youth, Woman or PWD.

e. Knowledge on Tendering and prequalification- Prequalification gives the Government the opportunity to know what businesses are in existence and running.

f. Source of Financing- Lack of capital is a major reason prompting the youth to shy away from seeking government tender prospects. The Youth need more insight on how to go about securing these funds. The Youth Enterprise Fund and Women Enterprise Fund have been expanded by the by relevant Ministries to offer Local Purchase Orders (LPO) and Local Service Orders (LSO) financing to the Youth and Women in Kenya.

Access to data and information on public contracts makes it challenging for regulators, auditors and the public to properly assess the integrity of the contracting process, assess the fairness, quality of public participation and feedback from communities Nduta et al. (2015). Further, Government agencies, citizens and civil society should be able to freely access and re-use public contracting data to reinforce the efficacy and sustainability of the AGPO initiatives.

Customer experience and support from AGPO secretariat and other support structures as Huduma Centers have been reported to operate with significant delays on inquiries about approvals and certification. Procuring entities need to adopt more proactive online disclosure practices, pursuant to Article 35 of the COK, 2010 and the Access to Information Act 2016, for all documents related to planning, awarding, implementation and oversight of AGPO contracts.

The UN Women Report 2016, noted some of the common challenges faced in AGPO to include the complex procurement procedures, hence being burdensome and costly for new entities, the public procurement contracts involve higher bid, proposal and compliance costs, most procurement criteria are very technical and require specialized bidding skills. This, in turn, inhibits the Youth, because most of them have a deficiency of business knowledge and skills to tender for Government contracts.

\section{Awareness Raising and Uptake of AGPO}

The Awareness Raising was studied as a causal variable and its bearing on Uptake of AGPO among the Youth. Awareness- Raising is a concept that has gained popularity in many societies and cultures. It refers to a process that creates opportunities for information exchange in order to advance reciprocated understanding and develop capabilities and requisite skills that are necessary to enable changes in social attitudes and behavior (Sayers, 2006). It has been applied to help people grasp issues that are wicked, upright or unresponsive. 
When effectively used, Awareness Raising fosters information and education among the target groups on various topical issues.

Awareness Raising on matters connected to Public Procurement would be an ultimate means of empowering marginalized communities and special groups to combat poverty and promote inclusive economic growth. This is geared towards transformation of attitude and mind-sets, behaviors and beliefs. It is envisioned that it supports the attainment of the desired objectives and behaviors, in this case the Uptake of AGPO by the Youth in Isiolo County.

The Youth when effectively engaged, have been found to possess the potential to accelerate productivity growth in the economy. However, they are usually left idle hence triggering social, political and economic instability and underdevelopment. Efficacious integration of the Youth in the economy through the government procurement opportunities expedites the suppression of poverty and creates a circle of growth and investment(Njeri \& Getuno, 2016). It is envisioned that effective use of Awareness Raising strategies aims to kindle enthusiasm, action, and most importantly change of attitudes and mind-sets of the Youth.

The Oxfam International Youth Parliament (2005), indicated that to meaningfully engage the youth in and effectively bring about constructive, equitable and sustainable change, Awareness Raising is a demanding process. This therefore, calls for diverse stakeholders to come together to develop and implement long lasting AGPO multi-sectoral intervention strategies such as:

a) Building Youth capacity through holding seamless workshops, conferences, seminars and forums that would constitute an excellent way to disseminate information on AGPO. By holding these events, the Youth are able to come together and listen to information as well as express their views and experiences. This will not only interest the Youth, but also encourages their involvement in AGPO.

b) Awareness Raising through Campaigns is another effective way of realizing the envisioned goals. Campaigns are based on the ability to communicate with a variety of audiences to get AGPO messages across the board. They are a deliberate effort to change practices, policies, behaviors and mind-sets among the Youth on AGPO. A best practice to promote use of campaigns would involve: researching AGPO Uptake; mobilizing supporters; informing the Youth and the general public on AGPO; and lobbying decision-makers.

c) It is also imperative to take cognizance of the fundamental and numerous talents that the Youth are endowed with and can be tapped to Raise Awareness on AGPO. Proper use of creative skills in drama, dance, art, music and acrobatics is an interactive approach that allows for an increased involvement of the Youth.

These creative approaches overcome diverse difficulties in engaging the Youth, due to factors brought about by issues such as illiteracy, lack of education, marginalization and disenfranchisement.

d) Technological advancement is the emerging trend of development, therefore, it's vital to take advantage of this inclination in order to succeed in passing key information in the society.

Leveraging on technology in this era of global communication is an important strategy of Raising Awareness on AGPO among the youth. Young people are active users of social media platforms such as Facebook, Instagram, LinkedIn, WhatsApp and twitter. Social media can be an effective tool for Awareness Raising on Uptake of AGPO that is, if the Youth have access to the internet, as it can contain loads of information on AGPO and can be highly interactive. 
Advertisements through radios, televisions, banners and newspapers are also effective, as information on AGPO is able to reach a high population of the Youth at the same time.

\section{The Research Gap}

In summary, most of the studies that were reviewed indicated that; access to finance, Legal and Regulatory Framework, ethics in procurement, are key determinants of AGPO by the Youth. The existing body of knowledge was not adequate to demonstrate the Primacy of the independent variable; Awareness Raising and the dependent variable Uptake of AGPO initiatives by Youth in Kenya.

The literature reviewed generally outlined the external environmental issues prompting participation of Youth in government business opportunities. The literature laid miniature weight on the strong bearing dynamics between intrinsic and extrinsic Awareness Raising matters such as the dissemination of Education Communication Materials, Knowledge on AGPO, Business Registrations and ownership. This study sought to fill the research gap by exploring the inspiration of Awareness Raising on Uptake of AGPO among the Youth in Isiolo County.

\section{Research Methodology}

The purpose of this study was to determine the primacy of Awareness Raising on the Uptake of AGPO.The study undertook a descriptive survey design. The study population targeted the Three (3) Sub-Counties, namely ; Isiolo,Garbatulla, and Merti in Isiolo County in Kenya. The target group constituted Fifty Five (55) Youth from Isiolo County that were attending a Course at the Kenya School of Government, Embu Campus. Questionnaires were used to collect data during the study. The questionnaire had closedended and open-ended questions.

The closed-ended questions made use of a five-point Likert scale where respondents were required to fill according to their level of agreement with the statements. Many researchers prefer to use a Likert-type scale because it's very easy to analyze statistically (Jackson, 2009). Frequencies and percentages which are part of descriptive statistics were used to analyze the

data.

The strength and direction of the relationship between the dependent variable and independent variable was measured using Pearson correlation coefficient. Correlation technique allowed the researchers to analyze the degree and direction of the relationship between the dependent and the independent variable.

\section{Operationalization of the Study Variables}

The responses in the questionnaire were rated on a scale of 1-5, where 1 represented strongly disagree and 5, strongly agree. Table 1 shows operationalization of the study variables.

Table 1. Operationalization of the Study Variables

\begin{tabular}{|c|c|}
\hline Variables & Indicators \\
\hline $\begin{array}{l}\text { Dependent Variable } \\
\text { (Uptake of AGPO) }\end{array}$ & $\begin{array}{l}\text { - } \text { Business Ownership Status } \\
\text { - Business Growth } \\
\text { - Business Profitability }\end{array}$ \\
\hline $\begin{array}{l}\text { Independent } \\
\text { Variable } \\
\text { (Awareness Raising) }\end{array}$ & $\begin{array}{l}\text { - I have full Awareness Raising on AGPO } \\
\text { - I am registered by the National Treasury on } \\
\text { the AGPO programme } \\
\text { - I get regular information on AGPO }\end{array}$ \\
\hline
\end{tabular}




\begin{tabular}{ll}
\hline Variables & Indicators \\
\hline & I have attended regular AGPO sensitization \\
& workshops \\
$\bullet$ & I regularly access information about AGPO \\
& on the print and electronic media \\
- & The knowledge I have on AGPO has enabled \\
& me to utilize the opportunity \\
- & I leverage on technology to access AGPO \\
& information \\
$\bullet$ & I effectively use social media such Facebook, \\
& Instagram, LinkedIn, WhatsApp and twitter. \\
\hline
\end{tabular}

(Source: Authors, 2019)

\section{Interpretation of the Correlation Coefficient of the Study Variables}

$H_{\mathrm{oi}}: \rho_{i}=\mathbf{0}$ versus $\mathrm{H}_{\mathrm{oi}}: \boldsymbol{\rho}_{i} \neq \mathbf{0}$

If the hypothesis is rejected then the Independent Variable $X_{i}$ had a statistically significant relationship or association with the dependent variable $Y$ (Chen \& Popovich, 2002).

The decision to reject or fail to reject the Null Hypothesis was based on the statistical significance of the correlation coefficient $(p \leq 0.05)$.

\section{Research Findings and Discussions}

This section reports the findings of the study. It begins with the respondents' response rate as indicated in Table 2, the respondents' demography, descriptive analysis of the study variables using proportions and culminates with the inferential statistics of the study variables using the Pearson's correlation coefficient $r$.

Table 2. Response Rate

\begin{tabular}{lccc}
\hline Item & $\begin{array}{c}\text { Administered } \\
\text { Questionnaires }\end{array}$ & $\begin{array}{c}\text { Returned } \\
\text { Questionnaires }\end{array}$ & $\begin{array}{c}\text { Percentage } \\
\text { Remaining }\end{array}$ \\
\hline Respondents & 55 & 55 & $100 \%$ \\
\hline
\end{tabular}

(Source: Authors, 2019)

\section{Respondents Demography}

\section{Respondents Gender}

From Table 3 and Figure 4, sixty-seven percent (67\%) of the respondents were male and thirty-three percent (33\%) were female.

\section{Table 3. Gender of Respondents}

$(\mathrm{N}=55)$

\begin{tabular}{rrc}
\hline Gender & $N$ & $\%$ \\
\hline Male & 37 & 67.0 \\
Female & 18 & 33.0 \\
$\mathrm{~N}$ & 55 & 100.0 \\
\hline
\end{tabular}

(Source: Survey Data, 2019) 


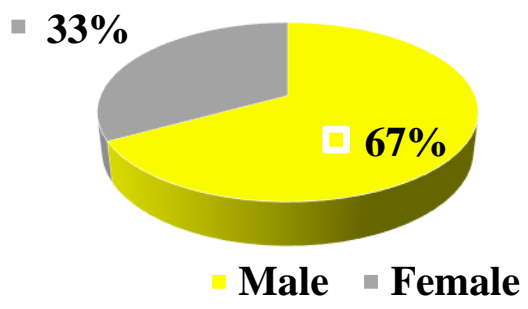

Figure 4: Gender of Respondents

(Source: Survey Data, 2019)

Age of Respondents

From Figure 5, seventy-three percent (73\%) of the respondents were between 20-29 years and twenty-seven percent (27\%) were between 30 -39 years.

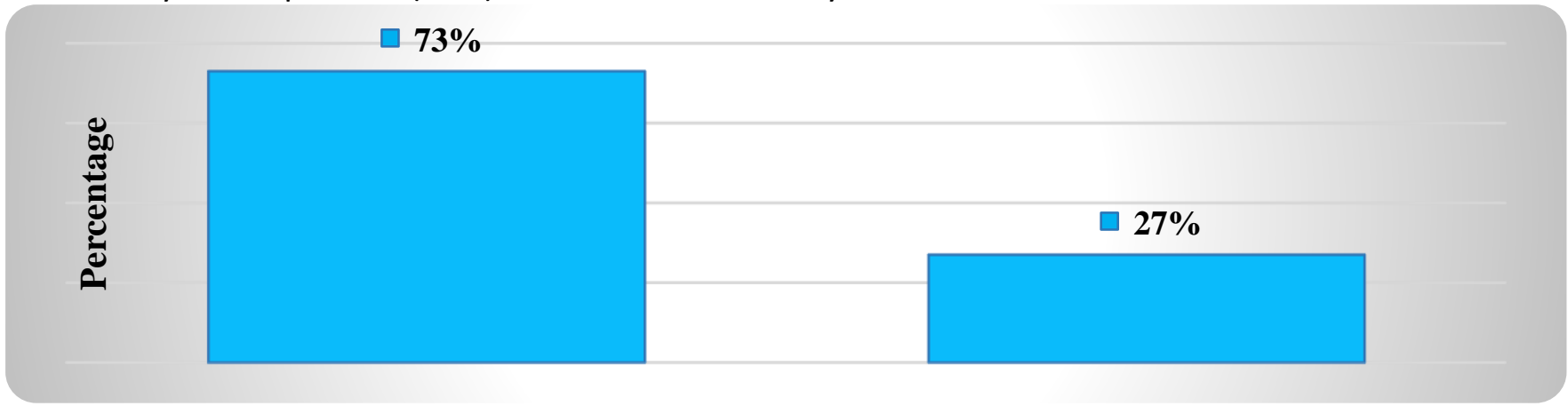

Figure 5: Age of Respondents

(Source: Survey Data, 2019)

Highest Academic Qualification

From Figure 6, sixteen percent (16\%) had KCPE, twenty-nine percent (29\%) had KCSE, twentyone percent (21\%) had Certificate, twenty-one percent (21\%) had Diploma and eleven percent (11\%) had a Degree.

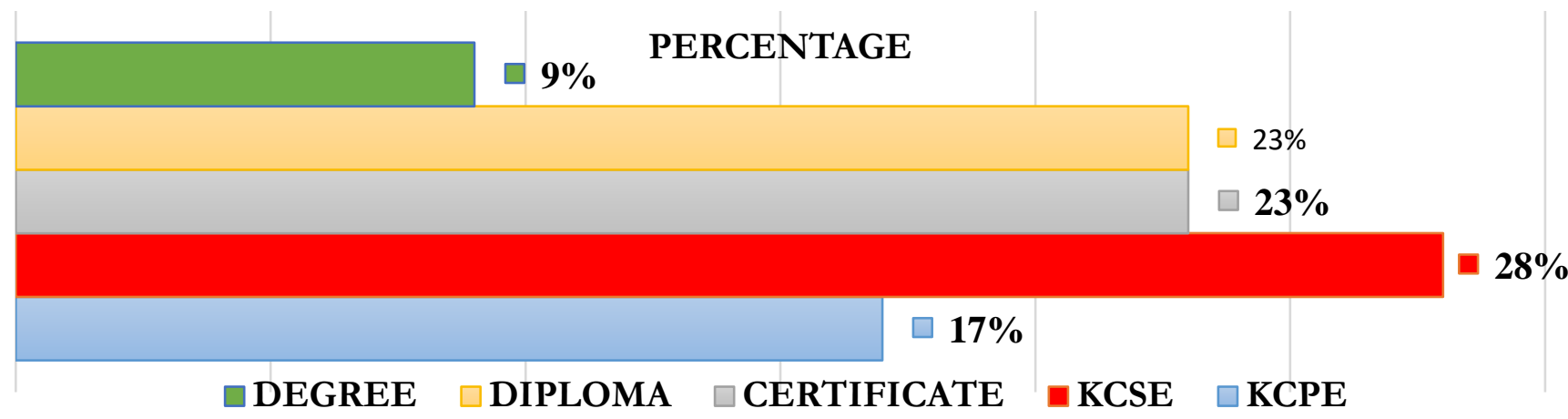

Figure 6: Respondents Highest Level of Education

(Source: Survey Data, 2019)

Respondents' Sub-County

From Table 4, majority of the respondents, that is eighty percent (80\%) were from Isiolo, eleven percent (11\%) from Garbatulla and nine percent (9\%) from Merti Sub County. 
Table 4. Respondents Sub-County

\begin{tabular}{rcc}
\hline Sub -County & $\boldsymbol{n}$ & \% \\
\cline { 2 - 3 } Isiolo & 44 & 80.0 \\
Garbatulla & 6 & 11.0 \\
Merti & 5 & 9.0 \\
$\mathrm{~N}$ & 55 & 100.0 \\
\hline
\end{tabular}

(Source: Survey Data, 2019)

The proportion of Respondents with Businesses

From Table 5 and Figure 7 forty-four percent (44\%) of the respondents owned some form of business while fifty-six percent (56\%) did not own a business.

Table 5. Business Ownership

(N = 55)

\begin{tabular}{rcc}
\hline Response & $\boldsymbol{n}$ & $\%$ \\
\hline Yes & 24 & 44.0 \\
No & 31 & 56.0 \\
N & 55 & 100.0 \\
\hline
\end{tabular}

(Source: Survey Data, 2019)

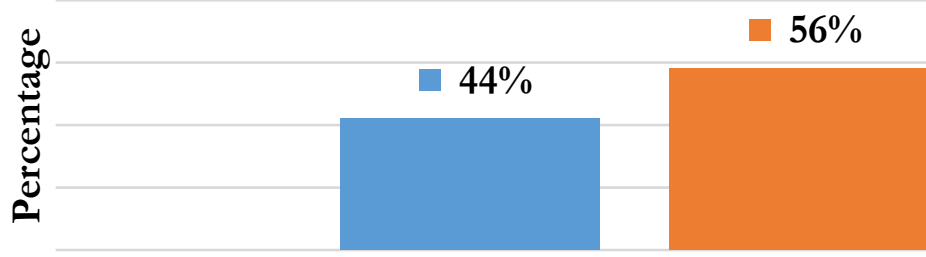

$\square$ Yes $n$ No

Figure 7: Respondents Business Ownership

(Source: Survey Data, 2019)

Type of Business Ownership

From Table 6 and Figure 8, sixty-two percent (62\%) had sole proprietorship type of business, twenty-seven percent (27\%) had partnerships and eleven percent (11\%) had limited companies.

Table 6. Type of Business Ownership $(\mathrm{N}=55)$

\begin{tabular}{rcc}
\hline Type of Business Ownership & $\boldsymbol{n}$ & $\boldsymbol{\%}$ \\
\hline Sole proprietorship & 16 & 62.0 \\
Partnership & 7 & 27.0 \\
Limited Company & 3 & 11.0 \\
$\mathrm{~N}$ & 26 & 100.0 \\
\hline
\end{tabular}

(Source: Survey Data, 2019) 


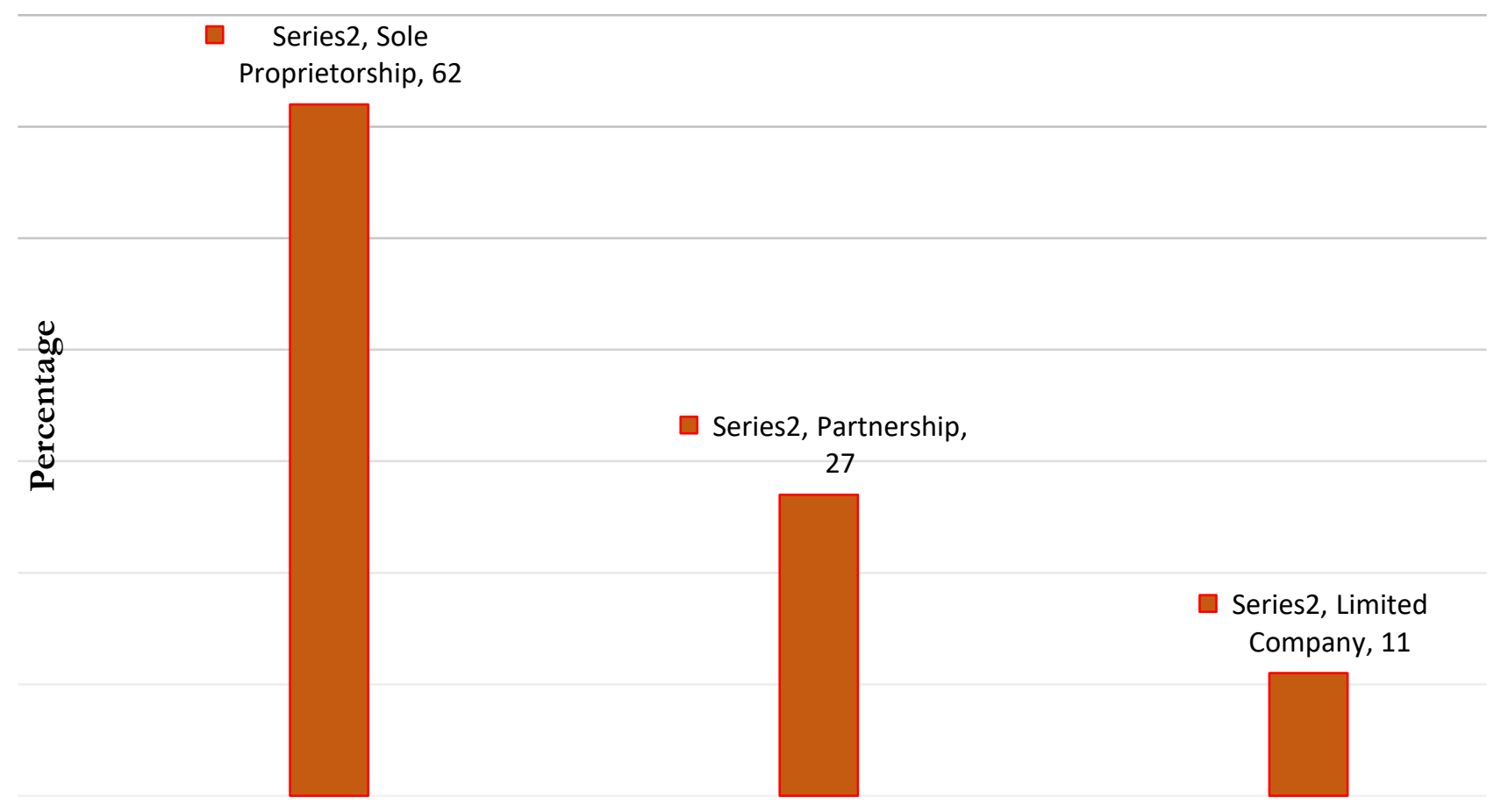

Figure 8: Business Ownership

(Source: Survey Data, 2019)

Cross Tabulation on Business Ownership and Type of Business Ownership

From Table 7 sixty-seven percent (67\%) owned a business and were sole proprietors.

Twenty-one percent (21\%) owned partnerships, whilst twelve percent (12\%) did own a business but were in Limited Companies. Twenty-nine percent (29\%) did not own a business but were in partnerships.

Table 7. Cross Tabulation-Business Ownership and Type of Business

\begin{tabular}{|c|c|c|c|c|c|c|}
\hline & & & \multicolumn{3}{|c|}{ Type of Business Ownership } & \multirow[t]{2}{*}{$\%$} \\
\hline & & & $\begin{array}{c}\text { Sole } \\
\text { Proprietorship }\end{array}$ & $\begin{array}{l}\text { Partner- } \\
\text { ship }\end{array}$ & $\begin{array}{l}\text { Limited } \\
\text { Company }\end{array}$ & \\
\hline \multirow{6}{*}{$\begin{array}{l}\text { Business } \\
\text { Ownership }\end{array}$} & \multirow{3}{*}{ Yes } & $N$ & 16 & 5 & 3 & 24 \\
\hline & & Do you own a business & $67.0 \%$ & $21.0 \%$ & $12.0 \%$ & $100.0 \%$ \\
\hline & & $\begin{array}{l}\text { What is the type of } \\
\text { Business Ownership }\end{array}$ & $100.0 \%$ & $71.0 \%$ & $100.0 \%$ & $92.3 \%$ \\
\hline & \multirow{3}{*}{ No } & $N$ & 0 & 2 & 0 & 2 \\
\hline & & Do you own a business & $0.0 \%$ & $100.0 \%$ & $0.0 \%$ & $100.0 \%$ \\
\hline & & $\begin{array}{l}\text { What is the type of } \\
\text { Business Ownership }\end{array}$ & $0.0 \%$ & $29.0 \%$ & $0.0 \%$ & $8.0 \%$ \\
\hline \multirow{3}{*}{\multicolumn{2}{|c|}{$\%$}} & $N$ & 16 & 7 & 3 & 26 \\
\hline & & Do you own a business & $62.0 \%$ & $27.0 \%$ & $11.0 \%$ & $100.0 \%$ \\
\hline & & $\begin{array}{l}\text { What is the type of } \\
\text { Business Ownership }\end{array}$ & $100.0 \%$ & $100.0 \%$ & $100.0 \%$ & $100.0 \%$ \\
\hline
\end{tabular}

(Source: Survey Data, 2019) 


\section{Descriptive Statistics of the Study Variables}

\section{Awareness Raising and Uptake of AGPO by the Youth in Isiolo County}

From Table 8 seventy-seven (77\%) of the respondents agreed that they had full Awareness Creation on AGPO. Eighty-one percent $(81 \%)$ disagreed that they had registered with the National Treasury on the AGPO program. Sixty-six percent (66\%) of the respondents disagreed that they do get regular information on AGPO. Sixty-seven percent (67\%) disagreed that they had attended regularly AGPO sensitization workshops.

Fifty-two percent (52\%) disagreed that they had regularly accessed information about AGPO on the print and electronic media. When the respondents were asked on whether the knowledge they had on AGPO, had enabled them to utilize opportunities, it was reported that fifty-one percent (51\%) agreed on this indicator.

Fifty -four percent (54\%) disagreed that they did leverage on technology to access AGPO information, and fifty-two percent (52\%) also disagreed on appropriateness use of available social media channels such as Facebook, Instagram, LinkedIn, WhatsApp and twitter to access AGPO Information.

Table 8. Descriptive Statistics of the Study Variable, Awareness Raising $(\mathrm{N}=55)$

\begin{tabular}{|c|c|c|c|c|c|c|}
\hline \multirow[t]{2}{*}{ Parameter } & $\begin{array}{l}\text { Strongly } \\
\text { Disagree }\end{array}$ & Disagree & $\begin{array}{l}\text { Don't } \\
\text { Know }\end{array}$ & Agree & Strongly Agree & $\%$ \\
\hline & \multicolumn{6}{|c|}{$\%$} \\
\hline $\begin{array}{l}\text { i. I have full Awareness } \\
\text { Creation on AGPO }\end{array}$ & 2.0 & 15.0 & 6.0 & 57.0 & 20.0 & 100.0 \\
\hline $\begin{array}{l}\text { ii. I am registered by National } \\
\text { Treasury on the AGPO } \\
\text { Programme }\end{array}$ & 26.0 & 55.0 & 4.0 & 9.0 & 5.0 & 100.0 \\
\hline $\begin{array}{l}\text { iii. I get regular information on } \\
\text { AGPO }\end{array}$ & 8.0 & 58.0 & 2.0 & 22.0 & 9.0 & 100.0 \\
\hline $\begin{array}{l}\text { iv. I have attended regular } \\
\text { AGPO rensitization } \\
\text { workshops }\end{array}$ & 19.0 & 48.0 & 6.0 & 19.0 & 9.0 & 100.0 \\
\hline $\begin{array}{l}\text { v. I regularly access information } \\
\text { about AGPO on the print and } \\
\text { electronic media }\end{array}$ & 9.0 & 43.0 & 7.0 & 28.0 & 13.0 & 100.0 \\
\hline $\begin{array}{l}\text { vi. The knowledge I have on } \\
\text { AGPO has enabled me to } \\
\text { utilize the opportunity }\end{array}$ & 8.0 & 38.0 & 4.0 & 38.0 & 13.0 & 100.0 \\
\hline $\begin{array}{l}\text { vii.I Leverage on Technology to } \\
\text { access AGPO information }\end{array}$ & 11.0 & 43.0 & 5.0 & 28.0 & 13.0 & 100.0 \\
\hline $\begin{array}{l}\text { viii. I appropriately use available } \\
\text { Social Media channels such } \\
\text { as Facebook, Instagram, } \\
\text { Linkedln, WhatsApp and } \\
\text { twitter to access AGPO } \\
\text { Information. }\end{array}$ & 10.0 & 42.0 & 6.0 & 29.0 & 13.0 & 100.0 \\
\hline
\end{tabular}

(Source: Survey Data, 2019) 


\section{Inferential Statistics of the Study Variable: Awareness Raising and Uptake of AGPO}

From Table 9, the independent variable, Awareness Raising had a statistically significant strong positive correlation with the dependent variable Uptake of AGPO $r(54)=.760 p<.05$ hence we REJECT the Null Hypothesis Ho1:Awareness Raising does not have a statistically significant relationship with the Uptake of AGPO by the Youth in Isiolo County.

Table 9. Correlation Coefficients between the Independent Variable (Awareness Raising) and the Dependent Variable (Uptake of AGPO)

Determinant of AGPO $\left(\mathrm{X}_{\mathrm{i}}\right)$ Uptake of AGPO (Y)

\begin{tabular}{lcc} 
& Pearson Correlation &. $\mathbf{7 6 0 *}$ \\
Awareness Raising & Sig. (2-tailed) & .011 \\
$\mathrm{~N}$ & 55 \\
\hline
\end{tabular}

*. Correlation is significant at the 0.05 level (2-tailed).

(Source: Survey Data, 2019)

\section{Conclusion and Recommendations \\ Conclusion}

The study established that, seventy-seven (77\%) of the respondents agreed that they had full Awareness Creation on AGPO. These findings concur with the scholarly works of Hivos, 2018, that majority of the Youth were trained by Public Procurement Boards, and that some organizations were conducting these trainings as way of fulfilling organizational contractual obligations such as Corporate Social Responsibility (CSR) Initiatives.

The study also found that, fifty- four percent (54\%) disagreed that they did leverage on technology to access AGPO information, and fifty- two percent (52\%) also disagreed on appropriate use of available social media channels such as Facebook, Instagram, LinkedIn, WhatsApp and twitter to access AGPO Information.

This is in consensus with findings from Hivos (2018) that a minority of the youth had accessed information from the AGPO website, and that newspapers were found to be inaccessible and an ineffective source of information for most of the Youth interested in AGPO opportunities. Notably, the findings are in congruence with the works of and Hivos, (2018) that found that a minority of the youth had undergone training on ways of applying Government Tenders, under AGPO and specifically had a lack of understanding of the bidding process. The study documented by Nduta et al. (2015) that, issues related to awareness on compliance, registration, effective regulations and financial availability influenced participation of the Youth in the Public Procurement.

The Seven Doors Social Marketing theory by Robinson demystified the notion that rigorous Awareness Raising does not automatically translate to momentous Uptake of AGPO, tangible results and by extension social change among the Youth (Sayers Richard, 2006)

\section{Recommendations}

From the findings, the study recommends that the National Government and County Government of Isiolo together with other Key Agencies such as Kenya School of Government and Development Partners should devise AGPO intervention strategies on ways of Awareness Raising among the Youth through: 
1. Infrastructural improvement that enhances use of advanced Technological and Communication channels.

2. Multi-sectoral approach in Regular Capacity Building Programs on AGPO Initiatives

3. Creation of Youth Talent Management centers that harness the fundamental and numerous talents that the Youth are endowed with and can be tapped to Raise Awareness on AGPO. This can effectively be realized through proper use of creative skills in drama, dance, art, music and acrobatics.

These recommendations shall expedite Awareness Raising on AGPO among the Youth on ways of competing favorably, by plunging into and growing entrepreneurial ventures, harnessing on the entrepreneurial skills and knowledge, thereby augmenting the attainment of Global, Regional and National Development Agendas.

\section{References}

Access to Government Procurement Opportunities (AGPO). (2015). Access to Government Procurement Opportunities (AGPO).Retrieved on February 15 2021, from Access to Government Procurement Opportunities (AGPO):www.agpo.go.ke

American Psychological Association. (2020). Publication manual of the American Psychological Association (7th ed.). https://doi.org/10.1037/0000165-000

Callaghan, C. W. (2009). A Dissertation Submitted to the Faculty Of Commerce, Law and Management, University of the Witwatersrand, Johannesburg, in Fulfilment of the Requirements for the Degree of Master of Commerce. Unpublished.

Deakins, D., \& Freel, M. (2012). Entrepreneurship and Small Firms Sixth Edition. McGrawHills Higher Education.

Gibb, A. A. (2000). 'Creating an entrepreneurial culture in support of SMEs', Small Enterprise Development, Vol 10, No 4, pp 27-38.

Government of Kenya. (2015). The Public Procurement and Asset Disposal Act, 2015. Nairobi: Government Printer Government of Kenya. (2013). Public Procurement and Disposal (Preference and Reservations (Amendment No.2) Regulations, 2013. Nairobi: Government Printer

Government of Kenya. (2013). The Public Procurement and Disposal (County Government) Regulations. Nairobi. Government Printers

Government of Kenya (GoK). (2005). The Public Procurement and Disposal Act, No. 3 of 2005.Nairobi: Government Printer

Hivos East Africa. (2018). Impact of Kenya' Access to Government Procurement Opportunities (AGPO) law on youth women and persons with disabilities. http:www.eastafrica.hivos.org

International Labour Organization. (2009). Inclusion of People with Disabilities in Kenya. Nairobi: International Labour Organization

International Trade Centre (ITC). (2014). Empowering Women through Public Procurement. Geneva, Switzerland

International Trade Centre. (2010). Understanding the Corporate Environment: MLS-SCM Course Book Module 1, United Kingdom: International Trade Centre

Jackson, S. L. (2009). Research Methods and Statistics: A Critical Thinking Approach 3rd edition. Belmont, CA: Wadsworth.

Kenneth, R. A. (1989). Ethics in Practice: Harvard Business Review pp. 99-104, Volume 67

Kothari. (2009). Quantitative Techniques(3rd Revised Edition). Nairobi: Vikas Publishing House PVT Ltd. 
Kenya Law. (2017). Retrieved from Laws of Kenya: http://kenyaaw.org Kenya National Bureau of Statistics (KNBS). (2010). The 2009 Kenya Population and Housing Census. Nairobi: Population Reference Bureau.

Kuratko, D. F., \& Hodgetts, R. M. (2007). Entrepreneurship in the New Millennium. Cengage Learning India private limited.

Lumpkin, R. D., \& Dess, G. G. (1996). Clarifying the Entrepreneurial Orientation Construct and Linking it to Firm Performance, Academy of Management Review.21,135-172.

Mahmood, M. (2010). 'British Must Move Fast to Profit on the Trade Front'. The Times 18th January 2005.

Mahmood, R., \& Hanafi, N. (2013). Entrepreneurial Orientation and Business Performance of Women Owned Small and Medium Enterprises in Malaysia. Competitive Advantage as a Mediator. International Journal of Business and Social Sciences. Vol.4.No.1.

Mapulanga, P. (2015). Public procurement legislation and the acquisition of library materials in academic libraries in Malawi. Library Review, 64(1), 101-117.

McCrudden, C. (2004). Using Public Procurement to Achieve Social Outcomes. Natural resources Forum 28 (pp. 257-267). Blackwell Publishing.

Muraguri, J. (2013).Implementation of the youth preference and reservation policy in Public Procurement. The case of state-owned enterprises in Nairobi. The University of Nairobi. Unpublished

Mwangi, P. N. (2017). Determinants of compliance with access to Government procurement opportunities regulations for special groups by public universities in Kenya.

Nduta, C., Ayuma, C., Langat, B., \&Yego, S. (2015). Factors Affecting Youth Participation in Public Procurement in Kenya: A Survey of Youth Enterprises in Mombasa County. The International Journal of Business \& Management. 3(9)2321 -8916.

Ngugi, J., \& Mugo, H. (2011). Internal factors affecting procurement process of supplies in public sectors. Journal of Public Procurement, 1.

Njeri, W. C., \& Getuno, P. (2016). Determinants for youth access to government procurement opportunities in Kenya: A case of judiciary. International Journal of Innovative Social Sciences \& Humanities Research, 4(3), 31-49.

Nkonge, B. K. (2013). Challenges faced by Small and Medium Enterprise Suppliers when bidding for tenders. A case of Thika District. International Journal of Academic Research in Business and Social Sciences, 3(12)194.

Obiri, L. (2016). Consultancy on the Assessment of the Uptake Of 30\% Public Procurement Business Opportunities for Women, Youth and Persons with Disability at the County Level and Availability of Business Development Services. Nairobi: Unwomen.

Odoyo, F., \& Lipindi, B. (2012). Compliance of Public Procuring Entities in Dar es Salaam. Kampala International University.

Public Procurement and Disposal Act. (2005). Kenya Gazette Supplement No. 77(Acts No. 3)

Public Procurement and Disposal General Manual. (2009). Public Procurement Oversight Authority. Public Procurement and Disposal Regulations (2013).

Public Procurement Oversight Authority. (2007). Assessment of the Procurement System in Kenya Public Procurement Oversight Authority. Retrieved from http://www.oecd.org/devt/effectiveness/41583965.pdf

Quinot, G. (2013). Promotion of Social Policy through Public Procurement in Africa. (pp. 370403). New York: Cambridge University Press.

Republic of Kenya. (2013). Economic recovery for wealth and employment creation (20032007) Nairobi: Government Printers 
Republic of Kenya. (2003).Kenya Vision 2030, A Globally Competitive and prosperous Kenya

Republic of Kenya. (2005). "Public Procurement and Disposal Act and Regulations" Nairobi: Government Printers

Richard, S. (2006). Principles of awareness-raising: Information literacy, a case study. Bangkok: UNESCO Bangkok.

Roodhooft, F., \& Abbeele, A. V. D. (2006). Public procurement of consulting services Evidence and Comparison with private companies. International Journal of Public Sector Management, 19(5) 490-512.

Scott, R. (2004). 'China's legal framework for public procurement'. Journal of Public Procurement Vol.3 (3) 370-388.

Simayi, S. (2005). Examination of Preferential Procurement, Enterprise Development and Corporate Social Investment with regards to the BEE draft codes of good practice Unpublished MBA Research Report, UCT Graduate School of Business.

Sutinen, J. G., \& Kuperan, K. (2009). A socio-economic theory of regulatory compliance. International Journal of Social Economics, 26(1/2/3) 174-193.

The Constitution of Kenya. (2010). Nairobi: The Government Printer, Nairobi Ugandan Experience. In G. Piga \& K. V. Thai (Eds.), Advancing Public procurement. Practices, Innovation and Knowledge-Sharing, 373-391

UNCITRAL. (2014). UNCITRAL Model Law on Public Procurement. Vienna, Austria: United Nations.

United Nations. (2017, 09 18). Retrieved from United Nations Global Market Place: https://www.ungm.org/Areas/Public/pph/index.html

Walker, H., \& Brammer, S. (2009). Sustainable Procurement in the UK Public Sector. Supply Chain Management: An International Journal, 14 (2): 128-37.

Wanderi, C. (2014). Kenya: New Public Procurement Rules Good for Business. The African Executive.

Wittig, W. A. (2003). Public Procurement and the Development Agenda, International Trade Centre, Geneva.

Wleh, N.P. (2013). Factors Influencing Youth Access To Public Procurement Opportunities In The Govrnment Ministries In Kenya. UON. Unpublished.

Oxfam International Youth Parliament. (2005). Case Study Collection: Awareness Raising \& Behavioural Change

Oxfam International Youth Parliament (OIYP) Oxfam Australia GPO Box 1711 Strawberry Hills NSW 2012 Australia 